УДК 94 (477.73) «18/19»

DOI: https://doi.org/10.33782/eminak2020.2(30).406

\title{
ДИНАМІКА ЦІН НА ЗЕМЛЮ НА ПІВДНІ УКРАЇНИ (ДРУГА ПОЛОВИНА ХІХ - ПОЧАТОК ХХ СТ.)
}

\author{
Ірина Міронова \\ Чорноморський національний університет імені Петра Могили (м. Миколаїв, Україна) \\ e-mail: ya.Irina761@gmail.com \\ ORCID: https://orcid.org/0000-0002-3039-742X
}

У статті розкрито основні фактори, причини й особливі чинники, які впливали на цінотворення землі у південному регіоні України в другій половині XIX - на початку XX ст. Особливу увагу приділено Селянській реформі 1861 р. і Столипінській аграрній реформі, які відігравали ключову роль у формуванні земельного ринку. Визначено роль Селянського поземельного та Дворянського земельного банків у фінансовому та земельному забезпеченні аграрного сектору економіки Південної України.

Ключові слова: земельний ринок, ціна землі, Селянська реформа 1861 р., Столипінська аграрна реформа, Селянський поземельний і Дворянський земельний банки

У сучасній Україні одним із пріоритетних і актуальних завдань держави є земельна реформа. Конституція зазначає, що власником українських земель є народ України. Утім, за роки Незалежності громадяни так і не отримали право вільно розпоряджатися цією власністю. Це свідчить про пережиток радянських часів в Україні та необхідність реформування земельного законодавства, що і має на меті земельна реформа. Ринок землі в Україні фактично діє, але у тіньовій і викривленій формі, від чого багато втрачають селяни, держава та легальні інвестори.

Відшукуючи оптимальні шляхи вирішення земельного питання, Міністерство розвитку економіки, торгівлі та сільського господарства України наголошує, що земельна реформа збільшить доходи мешканців села, запровадить чесні правила гри для легальних інвесторів, розвине фермерство та дрібне агровиробництво, встановить ринкові, а не корупційні ціни на землю. Але, разом з тим, небезпідставними побоюваннями українців $\epsilon$ те, що вся українська земля буде продана, олігархи скуплять ї̈ величезні площі, іноземці зможуть набувати у власність українські землі, селян змусять продавати свої паї, орендарів виженуть з орендованих ділянок, а також - ціна на землю буде штучно занижена. У зв'язку з цим, варто зауважити, що схожі питання вже виникали у селян, зокрема, під час проведення Столипінської аграрної реформи. Саме тому реформування земельного ринку за сучасних умов потребує вивчення історичного досвіду державних регулювань у галузі сільського господарства, а також використання позитивних складових реформ минулого.

Проблема реформування та розвитку сільського господарства, формування ринку землі в Україні, аналіз Селянської реформи 1861 р. та Столипінської аграрної реформи, $\epsilon$ предметом дослідження сучасних українських вчених О.Реєнта 1 ,

\footnotetext{
1 Реєнт О.П. Столипінська аграрна реформа: основні події, періодизація, особливості, наслідки // Український селянин. Збірник наукових праць. 2006. Вип. 10. С. 6-16.
} 
В. Шевченка², М.Якименка ${ }^{3}$, С. Корновенка ${ }^{4}$, О. Михайлюка ${ }^{5}$, О. Овдіна6, Г. Павельчика7 , О. Приймака8, Ю. Присяжнюка ${ }^{9}$ й ін. У своїх працях автори розкривають різні складові аграрних відносин другої половини XIX - початку XXст., з'ясовують процеси капіталізації сільськогосподарського виробництва, визначають регіональну специфіку проведення аграрних реформ, а головне - дають сучасну оцінку історичного минулого - реформування аграрного сектору. Водночас, питання цінової політики землі в окремих регіонах України, зокрема Півдня, в їх працях предметно не вивчалися. У зв'язку з цим, автор статті ставить за мету дослідити сутність, причини й особливі чинники, які впливали на цінотворення землі у південному регіоні України у другій половині XIX - на початку XX ст.

Згідно з висновками сучасних експертів, ціну на землю формують такі фактори: наявна до продажу площа земель, придатних для сільського господарства; законодавча база; різноманітні регіональні фактори; кліматичні умови країни та регіонів; близькість до інфраструктури; якість грунту; рельєф місцевості; ринкові умови (насамперед, баланс між попитом і пропозицією); правила продажу землі іноземцям10.

Природно-кліматичні умови південного регіону України були, у цілому, сприятливими для землеробства. Помітних прогресивних успіхів воно досягло з 30-х рр. XIX ст. переважно на території Херсонської та Катеринославської губерній 11 . Реформа 1861 р., крім основних завдань звільнення селян від кріпосної залежності, зумовила формування ринку землі та мобілізацію її від одних рук до інших, що природно спричинило підвищення цін на неї.

На початку XIX ст. земля на Півдні України, перебуваючи переважно у руках поміщиків, коштувала 1 руб. за десятину (1,0925 га). До 1830-х рр. вона підвищилася в ціні до 5-15 руб. за дес., а в Таврійській губернії ціна ії залишилася на цьому ж рівні і в $1860-$ - pp. ${ }^{12}$

За статистичними даними 1887 р. головними власниками землі у південному ре-

\footnotetext{
2 Шевченко В.М. Земельний ринок України (1861-1917 рр.): монографія. Ніжин: Аспект-Поліграф, 2010. $344 \mathrm{c}$.

3 Якименко М.А. Становлення селянського (фермерського) господарства в Україні після скасування кріпосного права (1861-1918рр.) // Український історичний журал. 1996. № 1. С. 3-13.

${ }^{4}$ Корновенко С.В., Герасименко О.В. Селянин-бунтар. Селянська революція в Україні 19021917 рр.: [монографія]. Черкаси: Чабаненко Ю.А., 2017. 204 с.

5 Михайлюк О.В. Столипінська аграрна реформа в контексті процесів розселянення сільського господарства на теренах Російської імперії // Український селянин. Збірник наукових праць. 2006. Вип. 10. С. 25-29.

6 Овдін О.В. Столипінська аграрна реформа на Катеринославщині (1906-1916 рр.): автореф. дис... канд. іст. наук: 07.00.01. Дніпропетровськ, 2005.19 с.

7 Павельчик Г.О. Регіональна специфіка проведення столипінської аграрної реформи на території України // Література та культура Полісся. 2012. Вип. 71. С. 174-184.

8 Приймак О.М. Столипінська аграрна реформа на Півдні України (1906-1917 рр.). Запоріжжя: Тандем-У, 2002. 188 с.

9 Присяжнюк Ю.П. Ментальні «почування» українського селянства в умовах проведення Столипінської аграрної реформи // Український селянин. Збірник наукових праць. 2006. Вип. 10. С. 2225.

10 Ціна землі в Україні: якою вона може бути? URL: https://landlord.ua/news/tsina-zemli-v-ukrainiiakoiu-vona-mozhe-buty/

11 Россия. Полное географическое описание нашего отечества. Настольная и дорожная книга. T. XIV. Новороссия и Крым / Под ред. В.П. Семенова-Тян-Шанского. Санкт-Петербург: Издание А.Ф. Девриена, 1910. С. 231.

12 Ibid. C. 240-241.
} 
гіоні України були приватні особи, яким належало більше половини всієї площі землі - 10 918,6 тис. дес. (50,9\%) із загального числа в 21 470,8 тис. дес. У Херсонській губернії переважало приватне землеволодіння, яке складало 53,1\% від загальної площі земельної власності. Друге місце належало селянським товариствам, які мали в наділі 40,4\% землі. Найбільші розміри селянська надільна власність мала у Катеринославській губернії $(45,6 \%)$ і найменші - у Херсонській $(34,4 \%)$. У Таврійській губернії площа селянських земельних наділів становила 39,4\%. Таким чином, селянські товариства та приватні особи були власниками 9/10 частини всієї земельної площі Південної України. На частку інших власників - скарбниці, міст, монастирів та інших установ - припадало менше $1 / 10$ частини.

Велика частка приватної землі $(58,1 \%)$ знаходилася у власності дворянського стану. Найбільший розвиток дворянське землеволодіння отримало у Катеринославській губернії, де воно становило 67,2\%, потім у Херсонській - 63\%. Найменший відсоток воно мало у Таврійській губернії - 43,9\%. Другим за кількістю землі особистим власником було селянство, яке володіло $1 / 5$ частини $(20,2 \%)$ усієї площі приватних земель (2206,2 тис. дес.). На противагу дворянському землеволодінню селянське найбільших розмірів досягло у Таврійській $(26,4 \%)$ і Катеринославській $(23,7 \%)$ губерніях, найменших - у Херсонській $(13,8 \%)$. Третє місце належало купецькому землеволодінню. Загалом купці мали 13,7\% всієї приватної землі регіону (1500,3 тис. дес.). Найбільша кількість землі знаходилася у руках купців Таврійської губернії $(17,9 \%)$, найменша - в Катеринославській (7\%). Наступним за кількістю землі в регіоні було землеволодіння духовенства, почесних громадян та ін. Їм належало 4,4\% (480,1 тис. дес.) усієї площі приватних земель Півдня України - в Таврійській губернії - 7,7\%, у Херсонській - 3,3\%, у Катеринославській - 0,4\%. У володінні ж міщан перебувало 3,6\% приватної землі (388,5 тис. дес.) - найбільше в Херсонській губернії $(5,5 \%)$ і найменше в Катеринославській $(1,7 \%)^{13}$.

Таким чином, щодо розподілу приватної землі між окремими станами власників (за винятком дворянського) Херсонська була губернією з найбільш розвиненим купецьким і міщанським землеволодінням, а Таврійська і Катеринославська - з селянським.

Період 70-80-х рр. ХІХ ст. характеризувався найбільш інтенсивною мобілізацією земельної власності із рук одного стану до іншого (див. Табл. 1).

Таблиця 1

Мобілізація земельної власності на Півдні України (1877-1887 рр.) ${ }^{14}$

\begin{tabular}{|l|c|c|c|c|c|}
\hline \multicolumn{1}{|c|}{ Губернії } & Роки & Дворян & Селян & Купців & Міщан \\
\hline \multirow{2}{*}{ Херсонська } & 1877 & 76,1 & 1,1 & 12,8 & 3,0 \\
\cline { 2 - 6 } & 1887 & 63,0 & 13,8 & 14,4 & 5,5 \\
\hline \multirow{2}{*}{ Катеринославська } & 1877 & 85,6 & 1,9 & 6,3 & 0,9 \\
\cline { 2 - 6 } & 1887 & 67,2 & 23 & 7,0 & 1,7 \\
\hline \multirow{2}{*}{ Таврійська } & 1877 & 60,4 & 3,8 & 17,7 & 5,6 \\
\cline { 2 - 6 } & 1887 & 43,9 & 26,4 & 17,9 & 4,1 \\
\hline
\end{tabular}

13 Ibid. C. 232-235.

14 Ibid. C. 235. 
Як можна побачити з даних таблиці, різке скорочення земельної власності по всіх губерніях відбулося лише у дворянському стані. Земельна ж власність інших станів, навпаки, значно збільшилася. За період 1877-1887 рр. дворянське землеволодіння найбільше скоротилося в Катеринославській (21,8\%) і Таврійській (21,7\%) губерніях. У Херсонській губернії дворянські землі зменшилися на 15,4\%. Селянська ж земельна власність, яка нараховувала в 1877 р. у південних губерніях (разом з Бессарабією) 205,9 тис. дес., до 1887 р. зросла до 2206,2 тис. дес., тобто збільшилася більше ніж у десять разів ${ }^{15}$.

Разом зі скороченням розмірів дворянської земельної власності зростала заборгованість приватного землеволодіння. Зазначимо, що дворянство Південної України мало велику заборгованість за землю ще у дореформений період. Так, до 1859 р., коли видачу позичок з державних кредитних установ під заставу поміщицьких маєтків припинили, сума боргів поміщиків у регіоні зросла до 9106,8 тис. руб., з яких 48\% припадало на Катеринославську губернію і 41\% - на Херсонську. Згідно з реформою 1861 р. у винагороду за поступку звільненим селянам надільної землі уряд призначив поміщикам певну суму, при видачі якої утримував ту ії частину, яка становила їхній борг кредитним установам. Таким чином, дореформені земельні борги приватного землеволодіння були погашені шляхом викупної операції. Але нові умови господарювання, викликані реформою, незабаром зумовили потребу в новому кредиті.

31864 р. виникла низка іпотечних установ (Херсонський земельний банк, Товариство взаємного поземельного кредиту тощо), і вже до 1870 р. борг приватного землеволодіння Херсонської губернії складав понад 9,6 млн. руб., Катеринославської 1 млн. руб. Зауважимо, що за величиною боргу Херсонська губернія на той час перебувала на першому місці серед інших губерній Російської імперії, а Катеринославська - на сьомому.

До 1 січня 1900 р. борг приватних землевласників Південної України сягав 336 млн. руб., що становило 1/5 частини $(23,5 \%)$ загальної суми іпотечного боргу приватних землевласників усієї імперії. По відношенню до всієї площі приватного землеволодіння регіону в заставі перебувало понад половини (55\%) всіх власницьких земель, що на 25\% перевищувало середній по всій імперії розмір заборгованості. У 1900 р. найбільша кількість приватної землі перебувала у заставі в Херсонській губернії - 76\%, у Катеринославській вона становила 68\%, Таврійській - 49\%16.

Збільшення заборгованості приватних землевласників супроводжувалося зростанням цін на землю, що не припинялося до початку XX ст. (див. Табл. 2).

Таблиця 2

Ціни на землю на Півдні України у 1868-1897 рр. (у руб.) ${ }^{17}$

\begin{tabular}{|l|c|c|c|c|c|}
\hline \multicolumn{1}{|c|}{ Губернія } & $\begin{array}{c}\mathbf{1 8 6 8 -} \\
\mathbf{1 8 7 7} \text { pp. }\end{array}$ & $\begin{array}{c}\mathbf{1 8 7 8 -} \\
\mathbf{1 8 8 7} \text { pp. }\end{array}$ & $\begin{array}{c}\mathbf{1 8 8 8}- \\
\mathbf{1 8 9 7} \text { pp. }\end{array}$ & $\begin{array}{c}\text { Підвищення ці- } \\
\text { ни у відсотках }\end{array}$ \\
\hline Херсонська & 27,1 & 42,2 & 88,3 & 55 & 109 \\
\hline Катеринославська & 24,7 & 36,9 & 80,5 & 49 & 118 \\
\hline Таврійська & 14,9 & 29,4 & 69,7 & 97 & 137 \\
\hline
\end{tabular}

15 Ibid. C. 235-236.

16 Ibid. C. 240-241.

17 Ibid. C. 242. 
Отже, як можна побачити з даних таблиці, за тридцять років вартість землі на Півдні України зросла майже втричі і продовжувала дорожчати й далі. Так, на Катеринославщині в 1898 р. середня вартість 1 дес. землі коштувала 104 руб., в 1903 р. 157 руб.18 У Херсонській губернії в 1900 р. вартість землі складала 141 руб. за дес., а в 1908 р. зросла до 191 руб. ${ }^{19}$ Найменшою залишалася вартість землі у Таврійській губернії, у 1910 р. ціна коливалася від 107 до 115 руб. за дес.20

Наступним важливим фактором, що визначав цінотворення землі, був існуючий у даній місцевості попит на землю та їі прибутковість. Це, у свою чергу, крім грунтових і кліматичних умов регіону, залежало від щільності населення та продовольчого прибутку. Цей фактор можна підтвердити на прикладі південноукраїнських губерній (див. Табл. 3).

Таблиця 3

Зв'язок ціни на землю зі щільністю населення і продовольчими прибутками на Півдні України (1888-1897 рр.) $)^{21}$

\begin{tabular}{|c|c|c|c|c|c|c|}
\hline \multirow[t]{2}{*}{ Губернія } & \multirow[t]{2}{*}{ 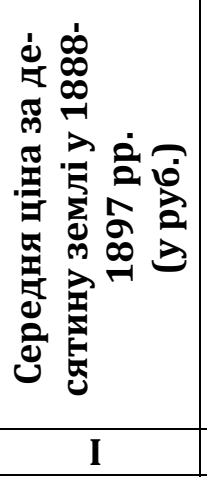 } & \multirow[t]{2}{*}{ 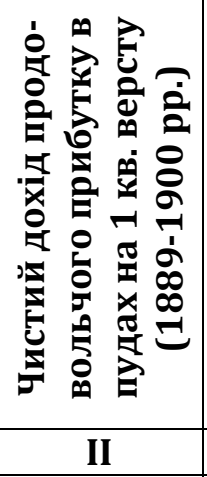 } & \multirow[t]{2}{*}{ 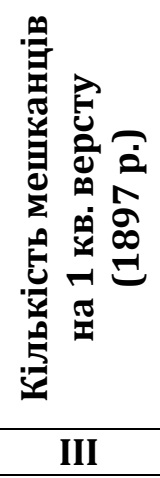 } & \multicolumn{3}{|c|}{ 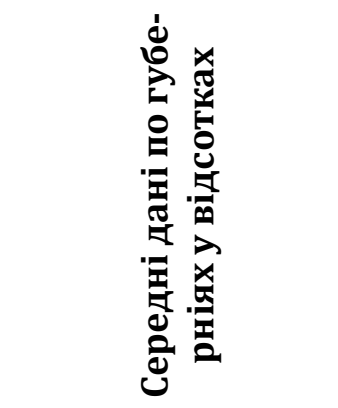 } \\
\hline & & & & I & II & III \\
\hline Херсонська & 88 & 1337 & 31 & 116 & 144 & 124 \\
\hline Катеринославська & 81 & 1215 & 33 & 107 & 122 & 132 \\
\hline Таврійська & 70 & 1072 & 30 & 92 & 108 & 120 \\
\hline
\end{tabular}

Наведені у таблиці дані показують тісний взаємозв'язок між ціною землі, їі продовольчим прибутком і щільністю населення. Так, високій щільності сільського населення щодо найбільшої з однієї одиниці площі збору хлібів у Херсонській губернії відповідала й найбільша ціна землі. Цілком зрозумілою за таких умов виглядає і швидкість росту ціни на землю в Південній Україні, оскільки їі зумовлювали такі найважливіші фактори як заселеність і розораність земель, які прогресували в ії губерніях швидше, ніж в інших частинах Російської імперії.

Також прямим наслідком швидкого зростання цін на землю було і зростання орендних цін на неї, що можна побачити у наступній таблиці.

\footnotetext{
18 Овдін О.В. Вказ. пр. С. 9-10.

19 Цибуленко Г., Цибуленко Л. Аграрна криза на тлі екологічної катастрофи в Херсонській губернії на початку XX століття // Scriptorium nostrum. 2015. № 3. С. 114.

20 Держархів Херсонської області (ДАХО). Ф. 44. Оп. 1. Спр. 431. Арк. 98.

21 Россия. Полное географическое описание нашего отечества. С. 243.
} 
Середня річна орендна плата за десятину ріллі в рублях ${ }^{22}$

\begin{tabular}{|l|c|c|c|}
\hline \multicolumn{1}{|c|}{ Губернія } & $\begin{array}{c}1881 \text { p. } \\
\text { (при оренді за } \\
\text { один рік) }\end{array}$ & $\begin{array}{c}\text { 1901 p. } \\
\text { (при оренді за } \\
\text { один рік) }\end{array}$ & $\begin{array}{c}\text { 1901 p. } \\
\text { (при оренді за } \\
\text { декілька років) }\end{array}$ \\
\hline Херсонська & 4,53 & 8,97 & 6,22 \\
\hline Катеринославська & 3,76 & 7,77 & 7,33 \\
\hline Таврійська & 3,37 & 8,65 & 4,15 \\
\hline
\end{tabular}

Як можна побачити з даних таблиці, по відношенню до середніх орендних цін на землю порядок губерній залишався такий самий, як і в попередній таблиці. Звернемо увагу на той факт, що в оренду землю здавали переважно малоземельні власники - духовенство, чиновництво та дрібне дворянство, власність землі яких не перевищувала 50 дес. У Херсонській губернії станом на 1905 р. вага їхніх господарств складала 22,48\%. Треба відзначити у цей період роботу муніципалітетів, які, попри прагнення задовольнити землею всіх бажаючих міщан, сприяли розвитку саме високорентабельних господарств, для чого проводили акції оренди з таким розрахунком, щоб міщанські сільськогосподарські ділянки зростали до 25 дес.

На початку XX ст. у Російській імперії існувало два типи оренди, що суттєво відрізнялися за характером виробничих відносин і виникали при користуванні орендною землею: голодна (продовольча) оренда найбідніших мас селянства та підприємницька оренда землі заможними селянами. При другому типі оренди заможні селяни орендували землю на декілька років, при цьому плата за землю коштувала їм дешевше при довгостроковій оренді й оренді великими ділянками. 3 цих орендованих селянами земель $40 \%$ перебувало в руках заможних селян. Наприклад, по Херсонський губернії орендувалося у 1900 р. 114,938 дес. у середньому по 495,4 дес. на одну операцію по ціні від 9 до 10 руб. за дес., у 1901 р. вже орендувалось 165,745 дес. по 560 дес. за операцію по ціні від 10 до 12 руб. (при оренді за один рік). Значні обсяги орендних ділянок свідчили про те, що вони орендувалися крупними виробниками. Оренда ж більшості селян була дрібною та не фіксувалася фінансовою системою губернії23.

Столипінська аграрна реформа, головними напрямками якої було виселення значної частини селян на окраїни імперії, зруйнування селянської общини й створення прошарку заможних фермерських господарств, зумовила нову хвилю ринкової мобілізації земельної власності, а відтак - і здорожчання землі. Основні завдання реформи полягали у тому, щоб за селянами закріпити у приватну власність землю. Для цього потрібно було надати кредити на їі придбання. Якщо взяти до уваги, що упродовж 1906-1914 pр. перехід на хутори та відруби сягнув значних розмірів, що потребувало ширшого застосування залізних плугів, упровадження технологій вирощування технічних культур та інших нововведень, то потреба фінансової підтримки виглядає очевидною24.

Головними локомотивами фінансового та земельного забезпечення аграрного

\footnotetext{
22 Ibid. C. 243-244.

23 Цибуленко Г., Цибуленко Л. Вказ. пр. С. 109, 111.

24 Присяжнюк Ю.П. Вказ. пр. С. 23.
} 
сектору економіки стали три банки: Селянський поземельний банк, Дворянський земельний банк і Земський банк.

9 (22) листопада 1906 р. видано указ, зміст якого стосувався звільнення селян із общини. Селянський банк зобов'язувався скуповувати поміщицькі садиби та продавати земельні паї селянам за пільговими цінами ${ }^{25}$. Пропонувався багаторічний кредит, що доходив до 90\% вартості землі при досить низькому відсотку (4,5\%, враховуючи погашення).У 1912 р. Селянський банк видав позики на 1 млрд. 168 млн. руб. ${ }^{26}$

Уряд розраховував на підтримку заможних селян, які повинні були першими покинути общину та зосередити у своїх руках більшу частину общинних, казенних і банківських земель, що були скуплені Селянським банком у поміщиків. Після указу 9 листопада розпочалася купівля земельних ділянок, укріплених за тими, хто залишив общину та подався у села. Такі наділи скуповували селянські багатії, які не обробляли цю землю, а негайно здавали в оренду та продовжували проживати в селі. Оскільки ціни на землю в українських губерніях були надзвичайно високі, то малоземельні охочіше залишали общину, щоб вигідніше продати укріплену ділянку або взяти позику ${ }^{27}$.

Селянський банк активно сприяв концентрації землі в руках крупних господарів. Намагаючись їх підтримати, банк розорював селян, підривав економічний стан їх господарства. Особливо у важкому стані знаходилися бідняки та середняки. Не маючи засобів для сплати в термін платежів за позиками, більшість їх розорювалася. У 1906 р. недоїмки за платежами банку складали 18,3 млн. руб. (75\% річного складу). Проте, вже на 1910 р. вони скоротилися до 9,1 млн. руб. Діяльність банку в Херсонській губернії була досить масштабною. Так, у 1900 р. ним було надано позик на придбання 8,127 дес., у 1904 - 146,730 дес. землі. У 1906 р. обсяги купівлі через банк знову скоротилися до 8 тис. дес., у 1908 р. склали 17,705 дес., а в 1913 р. лише 5,042 дес., що визначалося як спроможністю покупців, так і поступовим скороченням земельного ресурсу на ринку.

Окрім того, варто відзначити наявність цільового продажу банком землі. Це свідчило про ретельне відстеження ним ефективних господарств. У 1911 р. в Херсонській губернії банком було продано під хутори 273 ділянки середнім розміром 12,4 дес., під відруби з переселенням - 491 ділянку розміром 13,3 дес. і 137 - під відруби без переселення розміром 9,7 дес. ${ }^{28}$

У цілому, за підрахунками О. Приймака, за рахунок банківських послуг розмір приватного землеволодіння на Півдні України збільшили 16635 селян, що становило 1,7\% від загальної кількості сільського населення регіону. Унаслідок купівлі ділянок з фондів і при посередництві банку, 68\% його клієнтів підвищили розмір свого землеволодіння до рівня заможних селян, а $31 \%$ - до рівня селян-середняків ${ }^{29}$.

Треба відзначити той факт, що малоземельні селяни, у своїй більшості, ставилися негативно до діяльності Селянського банку. Зважаючи на те, що банк був великим земельним власником, селяни були впевнені, що політика банку має грабіжницький

\footnotetext{
25 Корновенко С.В., Герасименко О.В. Вказ. пр. С. 92.

26 Коваленко В.О. С.Ю. Вітте й П.А. Столипін: два погляди на одну проблему // Український селянин. Збірник наукових праць. 2006. Вип. 10. С. 18.

27 Реєнт 0.П. Вказ. пр. С. 7, 11-12.

28 Цибуленко Г., Цибуленко Л. Вказ. пр. С. 114-115.

29 Приймак О.М. Столипінська аграрна реформа на Півдні України (1906-1917 рр.): автореф. дис... канд. іст. наук: 07.00.01. Запоріжжя, 2002. С. 7.
} 
характер щодо них. Вигідна вона лише поміщикам і заможним селянам. За таких обставин селяни часто відмовлялися від купівлі землі у Селянського банка чи за його сприяння, від сплати грошових внесків банкуз3.

Іншим суттєвим недоліком була неузгодженість у роботі самих іпотечних банків. Так, якщо уряд за допомогою операцій Селянського банку із перепродажу землі намагався регулювати скорочення поміщицького землеволодіння та мобілізації земельної власності на користь селянства, то Дворянський банк своїми пільговими позиками штучно стримував розпродаж поміщицької землі. Це дозволяло поміщикам утримувати на високому рівні земельні ціни. У результаті, діяльність Дворянського банку перешкоджала розширенню селянського землеволодіння, у першу чергу приватного, а тому фактично суперечила завданням Столипінської аграрної реформи ${ }^{31}$.

Варто звернути увагу й на правила продажу банками державних земель. Згідно 3 указом від 19 травня 1912 р. державні землі перед продажем здавалися у шестирічну оренду із зобов'язанням вести поліпшене господарство за встановленою сівозміною. Такі землі могли бути продані лише після закінчення орендного терміну в разі точного виконання орендарем всіх зобов'язань. Для селян така попередня оренда була незрозумілою і не відповідала їх інтересам. Цілком природним було їх прагнення стати власниками земель, вносити платежі не в якості оренди, а як погашення боргу за купівлю32. Негативною стороною цього указу стало подорожчання державної землі. Так, у 1917 р. в Катеринославській губернії її продавали від 106 до 274 руб., у середньому - по 194 руб. за десятинуз3.

Одним з головних факторів цінотворення землі $\epsilon$ ринкові умови, що формують баланс між попитом і пропозицією. За підрахунками В.Шевченка, у межах дев'яти українських губерній, які входили до складу Російської імперії, упродовж 19061914 рр. було укладено 238,2 тис. торгових угод, спрямованих на продаж землі, i 248,7 тис. таких угод, спрямованих на ї̈ купівлю. Із них, на Півдні України було вчинено 54003 угоди купівлі (22,7\% від загальноукраїнського показника) і 45584 угод продажу землі (19,1\%). Усього за цей період було продано 2631713 дес. (36,9\%), куплено - 2753659 дес. землі (36,5\%). Лідером купівлі-продажу землі у регіоні була Херсонська губернія, де було вчинено угод з продажу землі - 19553, з купівлі 19 542; продано - 1158164 дес., куплено - 1146697 дес. землі. Другою за рівнем купівлі-продажу землі була Таврійська губернія (угод з продажу - 16 357, 3 купівлі 16 367; продано - 795229 дес., куплено - 887905 дес.), третьою - Катеринославська (угод з продажу - 9674, з купівлі - 18 094; продано - 678320 дес., куплено 719057 дес. $)^{34}$.

У цілому, земельний ринок Південної України виглядав найбільш збалансованим 3-поміж інших українських губерній. Цьому сприяли такі суттєві фактори, як наявність великих площ вільної землі, найнижча в Україні щільність населення, підпо-

\footnotetext{
30 Корновенко С.В., Герасименко О.В. Вказ. пр. С. 112.

31 Коріненко П.С., Терещенко В.Д. Проблеми державного кредитного забезпечення поміщицьких та селянських господарств в роки Столипінської аграрної реформи // Український селянин. Збірник наукових праць. 2006. Вип. 10. С. 32.

32 Ход крестьянского дела // Екатеринославский адрес-календарь. 1915 год. Екатеринослав: Губернская типография, 1915. С. 85-86.

33 Ход крестьянского дела // Екатеринославский адрес-календарь. 1917 год. Екатеринослав: Губернская типография, 1917. С. 38.

34 Шевченко В. Ринкова мобілізація земельної власності в роки столипінської аграрної реформи (на матеріалах України) // Сіверянський літопис. 2011. № 6 (102). С. 90-91.
} 
рядкування сільськогосподарського виробництва законам ринкової економіки, заселення краю іноземними колоністами-фермерами й ін. Як наслідок, у регіоні сформувались надзвичайно сприятливі умови для розвитку та еволюції земельного ринку. Землі тут продавалося й купувалося досить багато. Усе це сприяло тому, що за багатьма середньостатистичними показниками Південна Україна помітно переважала інші українські регіони ${ }^{35}$.

По всій Україні основною причиною продажу землі був пошук кращої ділянки - 3 допомогою переселення або купівлі більш привабливого (з точки зору розміру) землеволодіння ${ }^{36}$. Серед продавців землі, як і раніше, продовжували виділятися дворяни. Після поразки революції 1905-1907 рр. купівля дворянами земель почала відновлюватися, хоча й помітно поступалася ії̈ продажу. При цьому, в середовищі дворян дедалі помітною ставала тенденція до внутрішнього перерозподілу їхнього земельного фонду в напрямку концентрації земельних угідь у руках найбагатших дворянських родин. До активних продавців землі з початком XX ст. можна віднести також купців і банки. Перші, скупивши у 60-80-х рр. XIX ст. величезні земельні площі, з різким подорожчанням землі почали масово розпродувати їі, отримуючи від торговопоземельних операцій надвисокі прибутки. Банки ж, особливо Селянський, отримавши дозвіл на придбання земельної власності з метою її перепродажу, в роки аграрної реформи П. Столипіна, перетворились на справжніх лихварів не тільки щодо фінансового капіталу, але й щодо капіталу земельного. Серед покупців земельної власності найперше слід відзначити селян-одноосібників, чисельність яких помітно зросла у роки реформи, а також козаків і південноукраїнських колоністів. Серед колективних землевласників активними покупцями землі виявили себе селянські й інші товариства, залізничні та промислові компанії тощо 37.

Унаслідок проведення Столипінської реформи на Півдні України зменшилася площа державного, дворянського та купецького землеволодіння. За рахунок останніх збільшився розмір селянської земельної власності. Напередодні революційних подій 1917 р. він дорівнював 9914720 дес. і складав 56,2\% всієї території регіонуз8.

Зважаючи на головні сподівання П. Столипіна на створення прошарку «міцних і сильних» господарів, не менш важливим завданням для нього було й утримання основної маси селян від розорення та загибелі. Держава повинна була опікуватися селянами і захищати їх, у тому числі й від вторгнення розкладаючих впливів і руйнуючих ринкових відносин ${ }^{39}$. Тогочасна статистика навіть врахувала таку причину продажу землі черезсмужного володіння, як пияцтво. 3 цієї причини по всій Україні продали землю 1,3\% селян ${ }^{40}$. Безсумнівно, багатьох господарів бентежило, що власник, який укріпив свою землю, міг пропити її, продати за безцінь, а багаті селяни, скориставшись цим, могли скупити її велику кількість.

У зв’язку з почастішанням випадків марнотратства, що призводило до легковажного відчуження окремими господарями ділянок землі, 18 травня 1911 р. був прийнятий закон «Про заснування опіки над сільськими мешканцями внаслідок марно-

\footnotetext{
35 Ibid. C. 93.

36 Краснікова О.М. Фінанси і кредит у сільському господарстві Лівобережної України (друга половина XIX - початок XX ст.): історико-економічне дослідження. Полтава: РВВ ПДАА, 2018. С. 173174.

37 Шевченко В. Вказ. пр. С. 94.

38 Приймак О.М. Вказ. пр. С. 9.

39 Михайлюк О.В. Вказ. пр. С. 27.

40 Краснікова О.М. Вказ. пр. С. 173.
} 
тратства». Згідно з законом, на майно особи, визнаної волосним судом марнотратом, накладався арешт і призначалися опікуни. Волосне правління, у свою чергу, не мало право засвідчувати операції, що здійснювалися власником майна на ділянки общинної землі, які перебували у його користуванні 41 .

Стосовно побоювань селян, що багатії могли скупити всю землю, то уряд не надавав цьому факту важливого значення. Якщо кілька заможних селян скуповували по 100-300 дес., то придбати землю вони могли тільки за готівку, оскільки Селянський банк брав у заставу та видавав позики лише до певної норми. До того ж, застава землі в банку супроводжувалася наданням великої кількості документів (заява про видачу позики; умова сторін про купівлю-продаж землі; згода сільського товариства про укріплення землі; посімейно-майновий список покупця; план землі; заставне свідоцтво старшого нотаріуса й ін.). Після розгляду банком цих документів і дозволу на позику, вчинялися купчі, після затвердження яких могли бути видані позики. У результаті, процес отримання заставного свідоцтва затягувався на кілька місяців, а купча вчинялася упродовж одного-двох років.

Такий тривалий процес отримання позики під заставу надільних земель змушував селян продавати свої землі багатіям, які могли сплатити хоча б частину суми готівкою, за заниженою ціною, оскільки очікувати позики від Селянського банку означало залишитися на цілий рік без посіву та без доходів. Це й було основною причиною купівлі заможними селянами земель.

Також звернемо увагу й на той факт, що оцінка земель Селянським банком була майже вдвічі нижчою за існуючі ціни. Так, землі, не відведені до одного місця, продавалися на Півдні України у 1908 р. по 50-60 руб., в 1909 р. - по 100-150 руб. Відведені ж землі до одного місця у тих же селах продавалися по 200-300 руб. за десятину, а оцінка їх банком залишалася такою самою42.

Отже, ціна на землю на Півдні України від другої половини XIX - до початку XX ст. зросла майже на 200\% (у середньому від 15-25 до 200 руб. за десятину). Цьому сприяли такі фактори, як наявна до продажу площа земель, придатних для сільського господарства, найнижча в Україні щільність населення, підпорядкування сільськогосподарського виробництва законам ринкової економіки, баланс між попитом і пропозицією на землю. Водночас прискорене зростання ціни на землю було небажаним явищем, оскільки викликало негативне уявлення про нову форму володіння. Якщо за час від проведення Селянської реформи 1861 р. до Столипінської аграрної реформи цінову політику визначали переважно фактори зростання ринкового обігу землі, що спричиняло мобілізацію її від рук одного стану до іншого, то у період Столипінської реформи, крім вказаних явищ, одну з головних ролей у цінотворенні землі почали відігравати банківські установи. Неузгодженість уряду з діями банків та останніх поміж собою було однією з причин, яка призводила до посилення процесу концентрації великої кількості землі у руках заможних верств населення, тим самим, сприяючи розоренню малоземельних селян. Зрозуміло, що причини цієї неузгодженості лежали не в економічній, а в суто політичній площині. Намагаючись створити

41 Журнал Херсонского губернского присутствия. 1911 год июля 11 дня // Памятная книжка Херсонской губернии на 1912 год. Херсон: Типография Херсонского Губернского Правления, 1912. С. 28-31.

42 Иванов. Обзор деятельности землеустроительных комиссий Екатеринославской губернии за 1909 год // Адрес-календарь Екатеринославской губернии на 1910 год. Екатеринослав: ТипоЛитография Губернского Правления, 1910. С. 12-14. 
новий прошарок заможних селян-власників, уряд не міг не рахуватися з інтересами поміщиків, як головної соціальної опори самодержавства.

За оцінкою сучасних експертів, вартість землі сільськогосподарського призначення в Україні, після зняття мораторію, може становити 1,5-2 тис. дол. за гектар. Задля зменшення ризиків для сільськогосподарського виробництва (23\% українців вважають, що зняття мораторію на продаж землі дозволить скупити їі олігархам), у сучасних реаліях проведення земельної реформи уряду слід особливу увагу звернути на досвід вирішення земельного питання у попередні роки, удосконалити чинне земельне законодавство, а також узгодити кредитну політику банківських установ.

\section{REFERENCES}

Ivanov (1910). Obzor deiatelnosti zemleustroitelnykh komissii Yekaterinoslavskoi gubernii za 1909 god [Overview of the activities of land management commissions of the Ekaterinoslav province for 1909]. In Adres-kalendar Yekaterinoslavskoi gubernii na 1910 god (pp. 8-16). Yekaterinoslav [in Russian].

Korinenko, P.S., \& Tereshchenko, V.D. (2006). Problemy derzhavnoho kredytnoho zabezpechennia pomishchytskykh ta selianskykh hospodarstv v roky Stolypinskoi ahrarnoi reformy [Problems of State Credit Provision of Landlords and Peasants during the Stolypin Agrarian Reform]. Ukrainskyi selianyn, 10, 29-32 [in Ukrainian].

Kornovenko, S.V., \& Herasymenko, O.V. (2017). Selianyn-buntar. Selianska revoliutsiia v Ukraini 19021917 rr. [Peasant rebel. Peasant Revolution in Ukraine 1902-1917]. Cherkasy: Chabanenko Yu.A. [in Ukrainian].

Kovalenko, V.O. (2006). S.Yu. Vitte y P.A. Stolypin: dva pohliady na odnu problemu [S.Yu. Witte and P.A. Stolypin: two views on one problem]. Ukrainskyi selianyn, 10, 16-18 [in Ukrainian].

Krasnikova, O.M. (2018). Finansy i kredyt u silskomu hospodarstvi Livoberezhnoi Ukrainy (druha polovyna XIX - pochatok XXst.): istoryko-ekonomichne doslidzhennia [Finance and credit in agriculture of the Left Bank Ukraine (second half of XIX - beginning of XX century): historical and economic research]. Poltava: RVV PDAA [in Ukrainian].

Mykhailiuk, O.V. (2006). Stolypinska ahrarna reforma v konteksti protsesiv rozselianennia silskoho hospodarstva na terenakh Rosiiskoi imperii [Stolypin Agrarian Reform in the Context of Agricultural Settlement Processes in the Russian Empire]. Ukrainskyi selianyn, 10, 25-29 [in Ukrainian].

Ovdin, O.V. (2005). Stolypinska ahrarna reforma na Katerynoslavshchyni (1906-1916 rr.) [Stolypin Agrarian Reform in Katerynoslav Region (1906-1916)] (Extended abstract of Candidate's thesis). Dnipropetrovsk [in Ukrainian].

Pavelchyk, H.0. (2012). Rehionalna spetsyfika provedennia stolypinskoi ahrarnoi reformy na terytorii Ukrainy [Regional specifics of Stolypin agrarian reform in Ukraine]. Literatura ta kultura Polissia, 71, 174-184 [in Ukrainian].

Prysiazhniuk, Yu.P. (2006). Mentalni «pochuvannia» ukrainskoho selianstva v umovakh provedennia Stolypinskoi ahrarnoi reformy [Mental «feelings» of the Ukrainian peasantry in the conditions of Stolypin agrarian reform]. Ukrainskyi selianyn, 10, 22-25 [in Ukrainian].

Pryimak, 0.M. (2002). Stolypinska ahrarna reforma na Pivdni Ukrainy (1906-1917 rr.) [Stolypin Agrarian Reform in the South of Ukraine (1906-1917)]. Zaporizhzhia: Tandem-U [in Ukrainian].

Pryymak, O.M. (2002). Stolypinska ahrarna reforma na Pivdni Ukrainy (1906-1917 rr.) [Stolypin Agrarian Reform in the South of Ukraine (1906-1917)] (Extended abstract of Candidate's thesis). Zaporizhzhia [in Ukrainian].

Reient, O.P. (2006). Stolypinska ahrarna reforma: osnovni podii, periodyzatsiia, osoblyvosti, naslidky [Stolypin agrarian reform: main events, periodization, features, consequences]. Ukrainskyi selianyn, 10, 6-16 [in Ukrainian].

Semenov-Tian-Shanskii, V.P. (Ed.). (1910). Rossiia. Polnoie geograficheskoie opisanie nashego otechestva. Nastolnaia i dorozhnaia kniga. Novorossiia i Krym. (Vols. XIV). Sankt-Peterburg: Izdanie A.F. Devriyena [in Russian].

Shevchenko, V.M. (2010). Zemelnyi rynok Ukrainy (1861-1917 rr.) [Land Market of Ukraine (18611917)]. Nizhyn: Aspekt-Polihraf [in Ukrainian].

Shevchenko, V.M. (2011). Rynkova mobilizatsiia zemelnoi vlasnosti v roky stolypinskoi ahrarnoyi reformy (na materialakh Ukrainy) [Rynkova mobilizatsiia zemelnoi vlasnosti v roky stolypinskoi ahrarnoi reformy (na materialakh Ukrainy)]. Siverianskyi litopys, 6 (102), 89-95 [in Ukrainian].

Tsybulenko, H., \& Tsybulenko, L. (2015). Ahrarna kryza na tli ekolohichnoi katastrofy v Khersonskii 
hubernii na pochatku XX stolittia [Agrarian crisis against the backdrop of an environmental disaster in Kherson province in the early XX century]. Scriptorium nostrum, 3, 107-124 [in Ukrainian].

Yakymenko, M.A. (1996). Stanovlennia selianskoho (fermerskoho) hospodarstva v Ukraini pislia skasuvannia kriposnoho prava (1861-1918 rr.) [Formation of peasant (farmer) economy in Ukraine after the abolition of serfdom (1861-1918)]. Ukrainskyi istorychnyi zhurnal, 1, 3-13 [in Ukrainian].

\section{Irina Mironova}

(Petro Mohyla Black Sea National University, Mykolaiv, Ukraine)

e-mail: ya.Irina761@gmail.com

ORCID: https://orcid.org/0000-0002-3039-742X

\section{Land Price Dynamics in the South of Ukraine (Second Half of the $19^{\text {th }}-$ Beginning of the $20^{\text {th }}$ Century)}

The main factors and special reasons that influenced the land price formation in the southern region of Ukraine in the second half of the $19^{\text {th }}$ - the beginning of the $20^{\text {th }}$ century are presented in the paper. Among them were the areas of agricultural land available for sale, the lowest population density in Ukraine, the dependence of agricultural production on the laws of a market economy, the balance between supply and demand for land. It is noted that the Peasant Reform of 1861 and Stolypin Agrarian Reform played a key role in the formation of the land market and its price formation.

It is stated that the reform of 1861 gave impetus to increase the market turnover of land and led to its mobilization. The main reasons for the increase in land prices in the post-reform period were the reduction in the size of aristocratic land ownership, the arrears of private land ownership, the existing demand for land and its profitability, and rising rental prices for land.

It is proved that Stolypin Agrarian Reform caused a new wave of market mobilization of land ownership, which led to higher land prices. The role of the Peasants' Land Bank and the Nobles' Land Bank in the financial and land support of the agricultural sector of the South Ukraine economy is determined. It is stated that the above-mentioned banks acted mainly to the benefit of the well-to-do population, which led to the intensification of the process of large amounts of land concentration in their hands and contributed to the burst-up of land-poor peasants. It is traced that the price of land in the southern region of Ukraine from the second half of the $19^{\text {th }}$ to the beginning of the $20^{\text {th }}$ century increased by an average of $200 \%$ - from 15-25 to 200 rub. for a desiatyna.

Keywords: land market, land price, Peasant Reform of 1861, Stolypin Agrarian Reform, Peasants' Land Bank and the Nobles' Land Bank 